Hany Moneib /et al/ Engineering Research Journal 160 (December 2018) M113 - M129

\title{
Combustion Characteristics of Coal-Oil-Water Slurry in Furnaces
}

\author{
Motaz Mabrouk $^{1 *}$, Hany Moneib ${ }^{1}$, Mahmoud Shahein ${ }^{1}$, Mohamed Kamal $^{2}$ \\ ${ }^{1}$ Mechanical Power Engineering Department, Faculty of Engineering, Helwan University, Massaken \\ El-Helmia, P.O 11718, Cairo, Egypt. \\ ${ }^{2}$ Central Metallurgical Research and Development $\mu$ Institute, El -Tabbin, Cairo, Egypt. \\ *Corresponding author. Tel.: +20 1145425032 \\ E-mail address: motazmabrouk145@gmail.com
}

\begin{abstract}
The ever increasing demands for energy which is coupled with stringent environmental regulations have made research in this field a top priority worldwide. This situation have enforced scientists and researchers to introduce, develop alternative renewable energy as well as to implement the reuse of low grade fossil fuel (mainly coal; plentiful reserves) in parallel with the depleted oil and gas reserves while maintaining the conceptual policies of cost-effective clean energy.

The present thesis undertakes the simultaneous use of coal/oil/water mixture as an alternative fuel for use in boilers and industrial furnaces. The aim is -in one part- to develop a burner that ensures (i) stable burning of this mixture at varying operating condition, (ii) maximize the radiation flame properties of oil fames by the introduction of a proper percentage of pulverized, (iii) ease the supply of coal, oil to the combustion chamber by making a coal-oil-water slurries, (iv) overcoming the difficulties associated with startup, stabilization and efficient burning of standalone burning of pulverized coal and (v) comply with environmental regulations.
\end{abstract}


For that purpose, the conventional swirl stabilized coaxial oil burner is modified via the replacement of the central oil atomizing nozzle by a carefully designed low-pressure air assisted atomizer that permits simultaneous admission and atomization of the well mixed coal-oil-water slurry without causing nozzle clogging. Subsequently, the burner is coaxially fitted to a horizontal, cylindrical, water-cooled, laboratory-scale combustor having an inner diameter of $0.4 \mathrm{~m}$ and $2 \mathrm{~m}$ length. The pulverized coal From El-Maghara coal mine (Sinai, Egypt) of particle's size $\leq 30 \mu \mathrm{m}$, diesel oil No. 2 and pure water represent the constituents of the well-mixed fuel slurry. Experiments are conducted on selected flames having constant input heat throughput and different air/ fuel ratios for three different blends (on mass basis) of oil/coal/water as follows: (Case1: pure oil; reference case), (Case2: 80\%, 10\%, 10\%) and (Case 3: 70\%, 15\%, 15\%). The results are compared with the reference case when burning pure oil.

The combustion characteristics are defined in terms of the cumulative rate of the heat transfer to cooling water jacket, heat flux to combustor walls and radial and axial profiles of mean gas temperature together with the dry volumetric gas analysis of $\left(\mathrm{CO}_{2}, \mathrm{CO}, \mathrm{NO}_{\mathrm{x}}\right.$, $\mathrm{SO}_{\mathrm{x}}$ and $\mathrm{O}_{2}$ ) within the flame zone and at the combustor exit. The combustion efficiency is deduced from the measured results.

The results indicate a pronounced increase of both the heat transfer to the cooling jacket and the combustion efficiency for case 2 (10\% coal, $10 \%$ water), which is coupled with a decline of $\mathrm{NO}_{\mathrm{x}}$ emissions. Further increase in the percentage of coal and water in the fuel mixture (case 3) causes a pronounced deterioration of the overall combustion characteristics; indicating an upper limit of the loading ratios of coal and water to only $10 \%$ for each. The Egyptian coal is considered a significant alternative source of energy.

Keywords: —water - cooled combustor; bituminous coal; Egyptian coal-oil-water mixture; coal slurry. 


\section{1- Introduction}

History shows that world energy has been steadily increasing and also that a huge increase in the energy consumption has taken place in the last century[1]. It's increasingly desirable to search for alternative and renewable energy resources to be able to face the possible future energy crises. Coal-slurry fuels have emerged as viable technical alternatives for oil and gas in utility and industrial boilers. Despite current low prices and the abundance of oil, concerns over its long-term availability and price, as well as strategic considerations, make coal-slurry technology attractive. During the past twenty years, coal oil mixture and coal water mixture attracted the attention of many researchers, because they are coal-based liquid fuels that can be fed through pipelines and also can be used as boiler fuels replacing oil fuels. However, coal-oil slurry (COS) and coal-water slurry (CWS) have their disadvantages: coal -oil slurry has high viscosity, which lessens the saved oil; the combustion value of coal-water slurry is correspondingly low. In order to increase the combustion value of coal slurry and to reduce the viscosity, coal-oil-water slurry (COWS) was studied extensively[2]. Several investigators carried out their investigations on preparation and rheological properties of it as shown in table 1.

Table 1 Previous work of COWS researches.

\begin{tabular}{|c|c|c|c|}
\hline Authors & Type of Slurry & Surfactant & Findings \\
\hline 1. Zhu, H. et al. [2] & $\begin{array}{l}\text { Triplex Synfuel } \\
\text { Comprising: } \\
\text { - Light Oil } \\
\text { - Water } \\
\text { - Coal }\end{array}$ & $\begin{array}{l}\text { (i) } \begin{array}{l}\text { Nonionic surfactant } \\
\text { (Emulsifying Agent) }\end{array} \\
\text { Octyl Phenol Poly- } \\
\text { Ethenoxy Ether } \\
\text { (OP) } \\
\text { and } \\
\text { (ii) } \text { Anionic surfactant } \\
\text { (Dispersing Agent) } \\
\text { Petroleum Sulfonate } \\
\text { (PS) }\end{array}$ & $\begin{array}{l}\text { The two triplex } \\
\text { systems could be } \\
\text { kept stable and } \\
\text { homogeneous for } \\
\text { two months. }\end{array}$ \\
\hline 2. Qi, H. L. et al [3] & $\begin{array}{l}\text { Triplex Synfuel } \\
\text { Comprising: } \\
\text { - Gasoline } \\
\text { - Water } \\
\text { - Coal }\end{array}$ & $\begin{array}{c}\text { (i) Nonionic surfactant } \\
\text { (Tween 80) }\end{array}$ & $\begin{array}{l}\text { The optimum } \\
\text { prescription } \\
\text { COWSF was obtained } \\
\text { when the ratio of the } \\
\text { components by weight } \\
\text { was }\end{array}$ \\
\hline
\end{tabular}




\begin{tabular}{|c|c|c|}
\hline & & $\begin{array}{l}\text { C: } 45 \% \\
\text { W: } 30 \% \\
\text { O: } 25 \% \\
\text { The viscosity of } \\
\text { COWS significantly } \\
\text { decreased with } \\
\text { increasing temperature } \\
\text { (decreased with } \\
\text { increased shear rate in } \\
\text { the range of } 10 \mathrm{~s}^{-1} \text { to } \\
100 \mathrm{~s}^{-1.1} \text { ) } \\
\text { Stable triplex mixture } \\
\text { systems were prepared } \\
\text { when the addition } \\
\text { proportion of Tween } \\
\text { 80 was 2.0\%. }\end{array}$ \\
\hline $\begin{array}{l}\text { 3. Shukla, S.C.et al [4] } \\
\text { and } \\
\text { 4.Majumder, S.K.et.al [5] }\end{array}$ & $\begin{array}{l}\text { Triplex Synfuel } \\
\text { Comprising: } \\
\text { - Oil } \\
\text { - Water } \\
\text { - Coal }\end{array}$ & $\begin{array}{l}\text { Viscosity increase with } \\
\text { decrease in average } \\
\text { particle size of coal. } \\
\text { The decrease in size } \\
\text { leads to increase in the } \\
\text { irregularity and non- } \\
\text { free flow behavior as a } \\
\text { result fluidity } \\
\text { decreases. }\end{array}$ \\
\hline
\end{tabular}

\section{2- Objective}

From the previous work it can be seen that most researches concerned on the rheological properties of COWS fuel and studied the effect of chemical additives, temperature, coal particle size and the component content in the slurry on the slurry preparation and rheology. Rare researches were carried out to investigate the combustion characteristics of COWS and rare researches were carried out on the combustion characteristics on the Egyptian coal (EC) which is considered a huge resource of energy in Egypt and is not used wisely since it was discovered in 1959. So, in this study, we investigated the 
combustion characteristics of COW triplex synfuel containing light diesel oil (No.2), water and EC without using additives. Studies on the effect of coal loading in the slurry fuel also have been investigated to predict its effect on the combustion characteristics. Experiments were carried out under condition of constant input heat.

\section{3- Experimental}

\subsection{Materials}

The coal used in present work is bituminous coal has been provided from El maghara coal mine in Gabal El maghara region in Sinai by the Egyptian General Mineral Resources Authority-EGMSA, Cairo, Egypt. The experimental coal stocks were prepared in the Central Metallurgical Research and Development Institute (CMRDI). The coal sample has been primarily crushed and sieved in standard sieves. This was followed by pulverization in a ball mill (dry grinding) to prepare a stock. The resulting coal powder had a particle size of $\leq 30 \mu \mathrm{m}$. The proximate analysis is shown in Table 2, S.S. Ibrahim, et al.[6]. Diesel oil NO.2 was used for suspension preparations. The proximate analysis of diesel oil No.2 is presented in table 3. Pure water of specific gravity 0.996 at $30^{\circ} \mathrm{C}$ has been taken for the experiments.

\subsection{Sample Preparation}

COW suspension is prepared on mass percentage basis. It was carried out in a cylindrical tank of $48.5 \mathrm{~cm}$ inner diameter in which three baffles of $4 \mathrm{~cm}$ in width and $30 \mathrm{~cm}$ length have been attached to inner walls are used for agitation. An axial stirrer of a three-bladed paddle type impeller with an impeller diameter of $11.5 \mathrm{~cm}$. The blade is of width of 3.2 $\mathrm{cm}$ and of $9 \mathrm{~cm}$ length. A known amount of diesel oil No.2 is initially fed into the fuel tank. Then a known amount of coal is slowly added such that most of the coal is soaked in oil. The remaining amount of oil is then added and continuously stirred for 10-15 min using the axial stirrer.

A Known amount of water to prepare the required COW slurry composition is then added and stirred again and so on. Stirring lasted for 3 hours with a speed of $750 \mathrm{rpm}$. This 
procedure of preparing a sample minimizes the risk of trapping air inside the coal powder and further reduces the problems of sedimentation. Thus the samples for experimental studies have been prepared with varying the composition of COW slurry.

Table 2.Proximate analysis of El-maghara coal

\begin{tabular}{cc}
\hline Constituent & Wt $\%$ \\
\hline Moisture & 2.12 \\
Ash & 8.26 \\
Volatile matter & 51.39 \\
Fixed carbon & 38.6 \\
Total sulfur & 2.9 \\
Calorific value & $6900-72022 \mathrm{Kcal} / \mathrm{kg}$ \\
\hline
\end{tabular}

Table 3.Proximate analysis of No.2 diesel oil

\begin{tabular}{cc}
\hline Constituent & $\mathrm{Wt} \%$ \\
\hline Carbon & 85.5 \\
Hydrogen & 13.2 \\
Sulfur & 0.1 \\
Oxygen & 0.2 \\
Calorific value & $42 \mathrm{MJ} / \mathrm{kg}$ \\
\hline
\end{tabular}

\subsection{Combustion Facility}

The general layout of the experiment test rig is presented in Fig.1.

\subsubsection{The combustor}

The combustor is a horizontal cylindrical water-cooled flame tube of $0.4 \mathrm{~m}$ inside diameter and $2.0 \mathrm{~m}$ length, manufactured of thick steel sheet of $0.007 \mathrm{~m}$ thickness. The flame tube is cooled by water jacket of $0.5 \mathrm{~m}$ outer diameter and segmented to 9 adjacent segments having progressively increased length along the flame tube. A $0.057 \mathrm{~m}$ 
diameter main cooling water header at underneath of the combustor distributes the cooling water to each segment via $0.0185 \mathrm{~m}$ diameter inlet pipe at bottom of each segment. The water flow rates are controlled by the regulating valves located at the entrance of each segment. The hot water leaves the segment at the top where the outlet temperature is measured by standard type $\mathrm{K}$ thermocouple, then via an individual tube to the collecting water tank where it is directed afterwards to the sink. At the middle of each segment, a radially aligned measuring hole of $0.0185 \mathrm{~m}$ bore diameter is provided to allow the insertion of the different measuring probes. The front side of the combustor is covered by a welded flange having a central hole of $0.135 \mathrm{~m}$ diameter. This flange is equipped by 4 studs to fix the burner coaxially to the combustor. The rear side of the combustor is connected to a chimney then to the atmosphere. The detailed construction of the combustor is shown in Fig.2.

\subsubsection{The coal-oil-water slurry burner}

The burner facility was specifically designed and constructed for use with coal slurries (COS and COWS).The burner facility is constructed from a thread T-connection of $0.3 \mathrm{~m}$ length with $0.105 \mathrm{~m}$ inside diameter and a cylindrical housing of $0.35 \mathrm{~m}$ length and 0.105 $\mathrm{m}$ outside diameter. The secondary combustion air swirler of $0.09 \mathrm{~m}$ diameter having a vane angle $30^{\circ}$ is inserted inside this housing. The swirler has 10 vanes made from a steel sheet of $0.0015 \mathrm{~m}$ thickness. A low pressure, air- assisted externally atomizing nozzle as shown in Fig.3 is connected to the fuel nozzle holder and inserted at the center of the secondary air swirler. The combustion air was fed to the burner by a high pressure air storage system and the atomizing airstream was fed to flow through the atomizing air holes encircling the atomizing nozzle [7]. 
Hany Moneib /et al/ Engineering Research Journal 160 (December 2018) M113 - M129

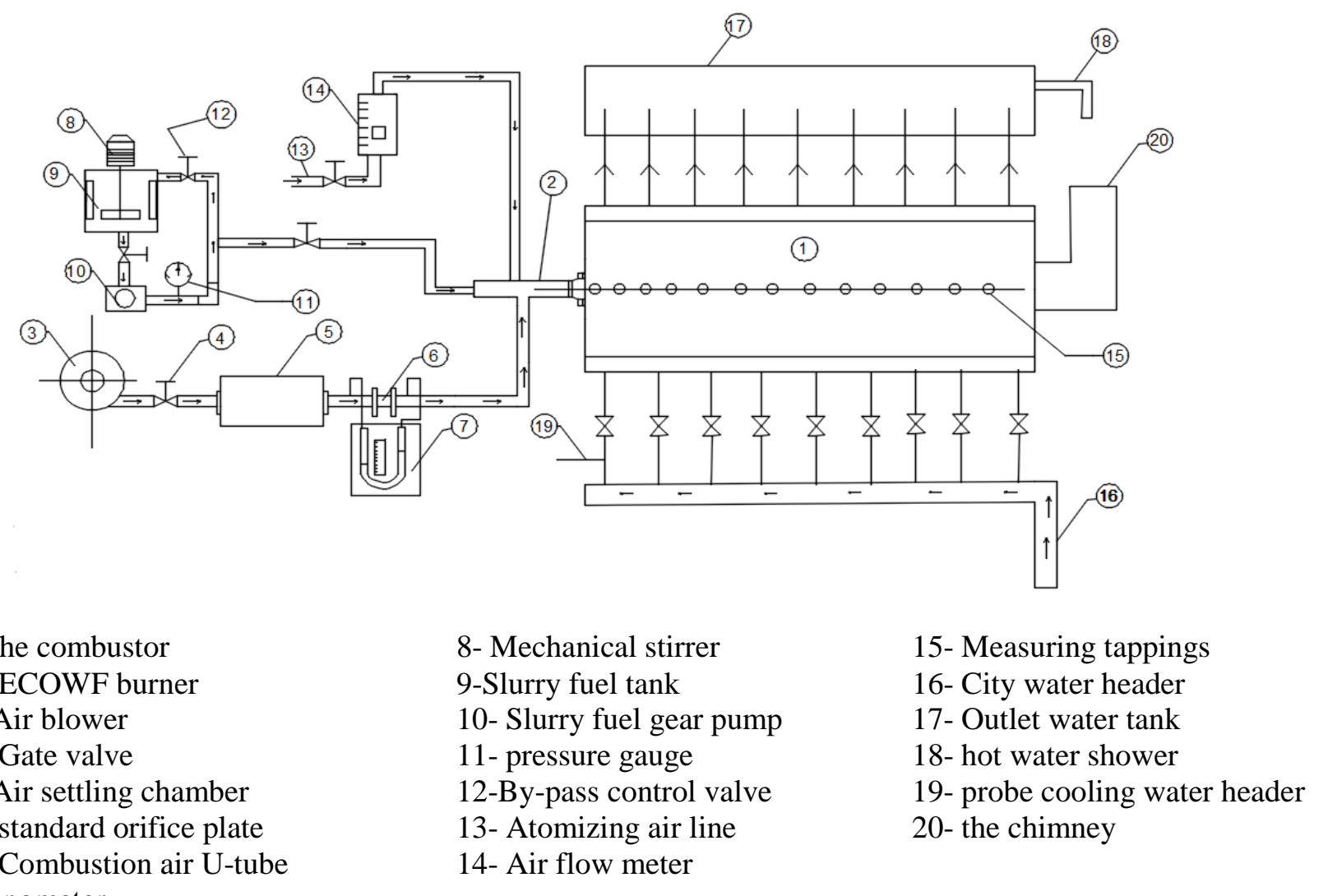

Fig. 1 The general layout of the test rig. 
Hany Moneib /et al/ Engineering Research Journal 160 (December 2018) M113 - M129

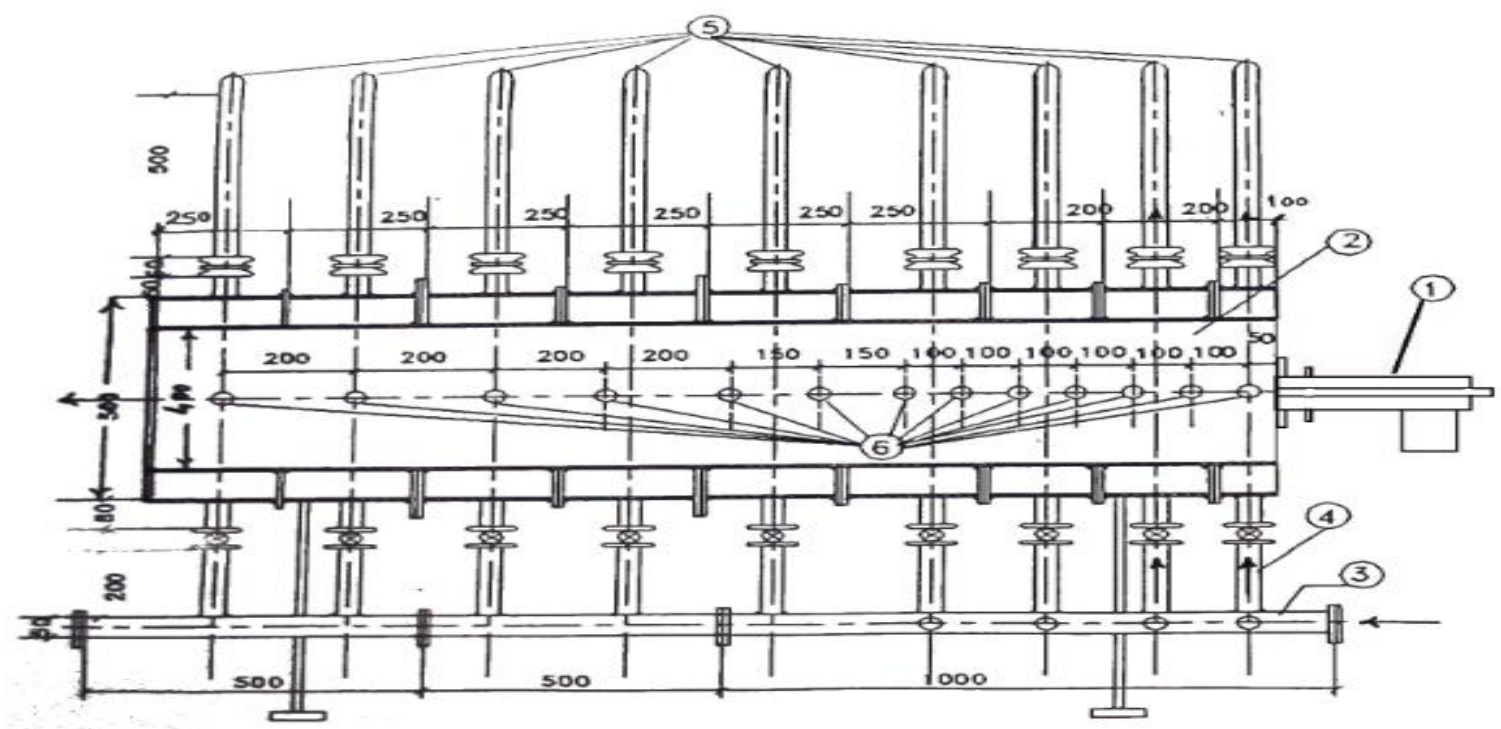

1-The coal-oil-water slurry fuel burner

4-Cooling water inlet

2-The combustor

5-Cooling water outlet

3-City water header

6-Measuring tappings

Fig.2 Sectional elevation of the coal-oil-water slurry fuel burner and the combustor.

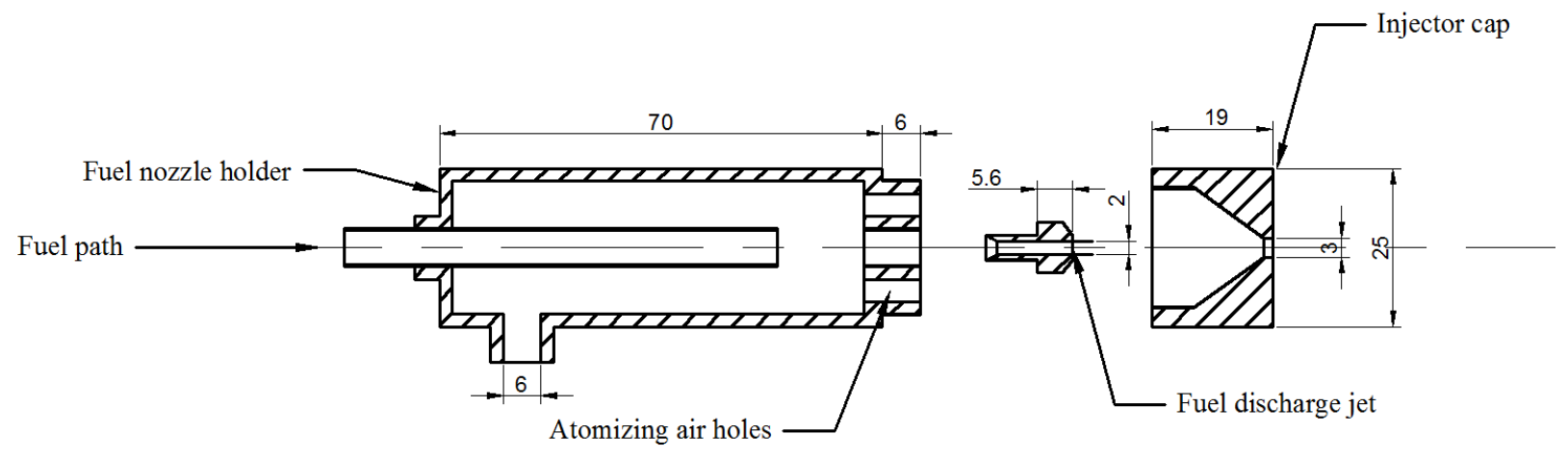

Fig.3 COWS nozzle used in combustion tests. 


\subsubsection{Secondary air supply system}

The combustion air is supplied to the burner by an electric blower of 7 HP. A reservoir of rectangular cross section $0.5 \times 0.5$ and $1 \mathrm{~m}$ length is constructed from steel sheet of 0.025 $\mathrm{m}$ thickness and connected to the blower outlet by a rectangular flange. This reservoir (air settling chamber) is used to minimize the fluctuation in pressure resulting from the air blower hence ensuring constancy of flow rate throughout the range of blower operation. The exit of this reservoir is contracted to $0.105 \mathrm{~m}$ diameter circular outlet tube. This tube is connected to the air supply line a flexible hose. The air flow rate is measured by a standard calibrated orifice plate. The head across it is measured by a U-tube water manometer.

\subsubsection{Primary air supply system}

The atomizing air is supplied to the burner by a compressor of $4 \mathrm{HP}$ with a flexible hose of $0.008 \mathrm{~m}$. the atomizing air flow rate is measured by the air flow meter which was calibrated with a bellows meter at different pressures of 1,2,3 bars. The pressure of atomizing air is controlled by a pressure regulator.

\section{4- Results and Discussion}

Figure 4 shows the distribution of flame temperature along the axis of the combustor for different percentages of EC and pure water in the diesel oil. Flame temperatures were measured by a type $S$ (Platinum/rhodium) traverse thermocouple probe. For run 1(pure diesel oil), the maximum temperature of the flame occurred in the end of the second segment at an axial distance $X=25 \mathrm{~cm}(X / D=0.625)$, at which the mixing of air and fuel was nearly completed at the stoichiometric air: fuel ratio. While the EC and pure water were added to the diesel oil as follow, (Run 2: 10\%, 10\%) showed that The maximum flame temperature slightly decreased due to the low calorific value of the coal compared to the diesel oil in addition to the nearby zero calorific value of water, also started to shift towards the third segment at axial distance $\mathrm{X}=35 \mathrm{~cm}(\mathrm{X} / \mathrm{D}=0.875)$.. This was probably 
due to faster mixing of pure diesel oil and air, which resulted in a faster chemical reaction and burning rate compared with the ECOWS fuel. Increasing the loading of the EC and water in the slurry further (Run 3: 15\%, 15\%), decreased the maximum flame temperature than these of run 1 and 2, and occurred at the end of the second segment at axial distance $25 \mathrm{~cm}(\mathrm{X} / \mathrm{D}=0.625)$. This decrease in temperature was due to increasing the ratio of water in the slurry, which is considered an incombustible matter. Also the water vapor produced restrains the chemical reaction rate and increasing the combustion time.

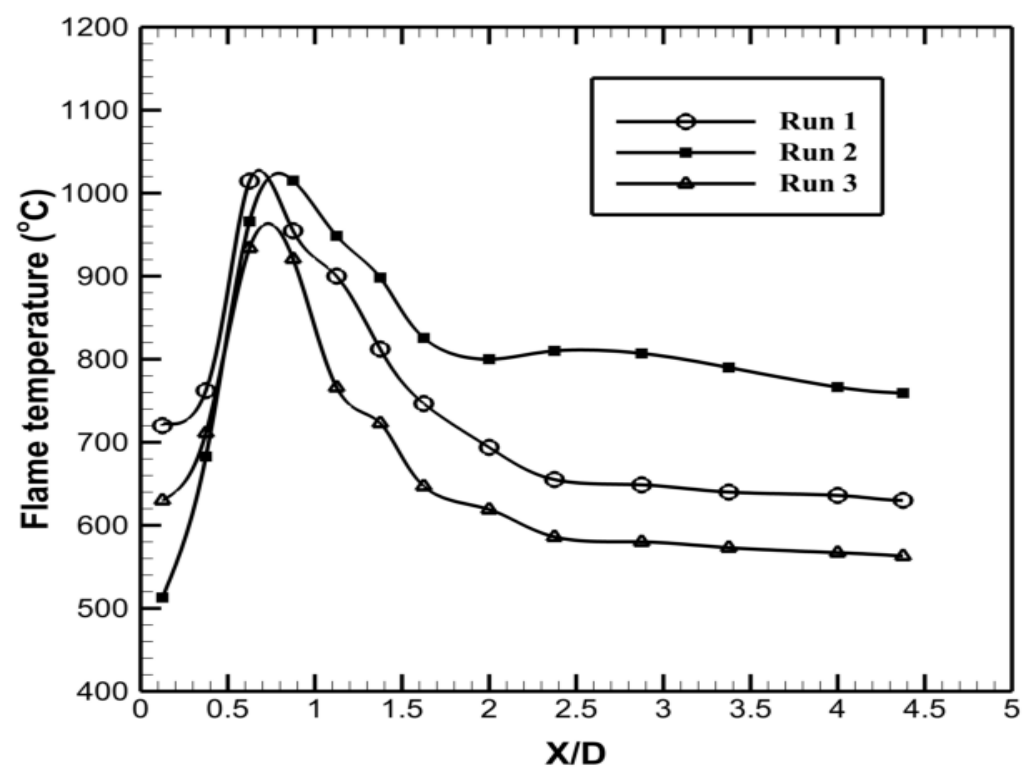

Fig.4 Axial distribution of flame temperature for different Percentages of EC and water in diesel oil.

Figure 5 presents the radial profiles of flame temperature of the three flames at an axial distance $X=25 \mathrm{~cm}(X / D=0.625)$. The same trend of variation of the radial profiles is attained along the flame diameter in the three runs. Run 2 exhibits larger flame diameter, so wider volume of central recirculation zone as shown in the figure within $0.5 \leq \mathrm{r} / \mathrm{R} \leq 0.8$ than these of the reference case (run 1: pure diesel oil) and run 3 ensuring higher chemical reaction zone; in which better mixing between primary jet of the atomizer and the secondary air stream is obtained. 


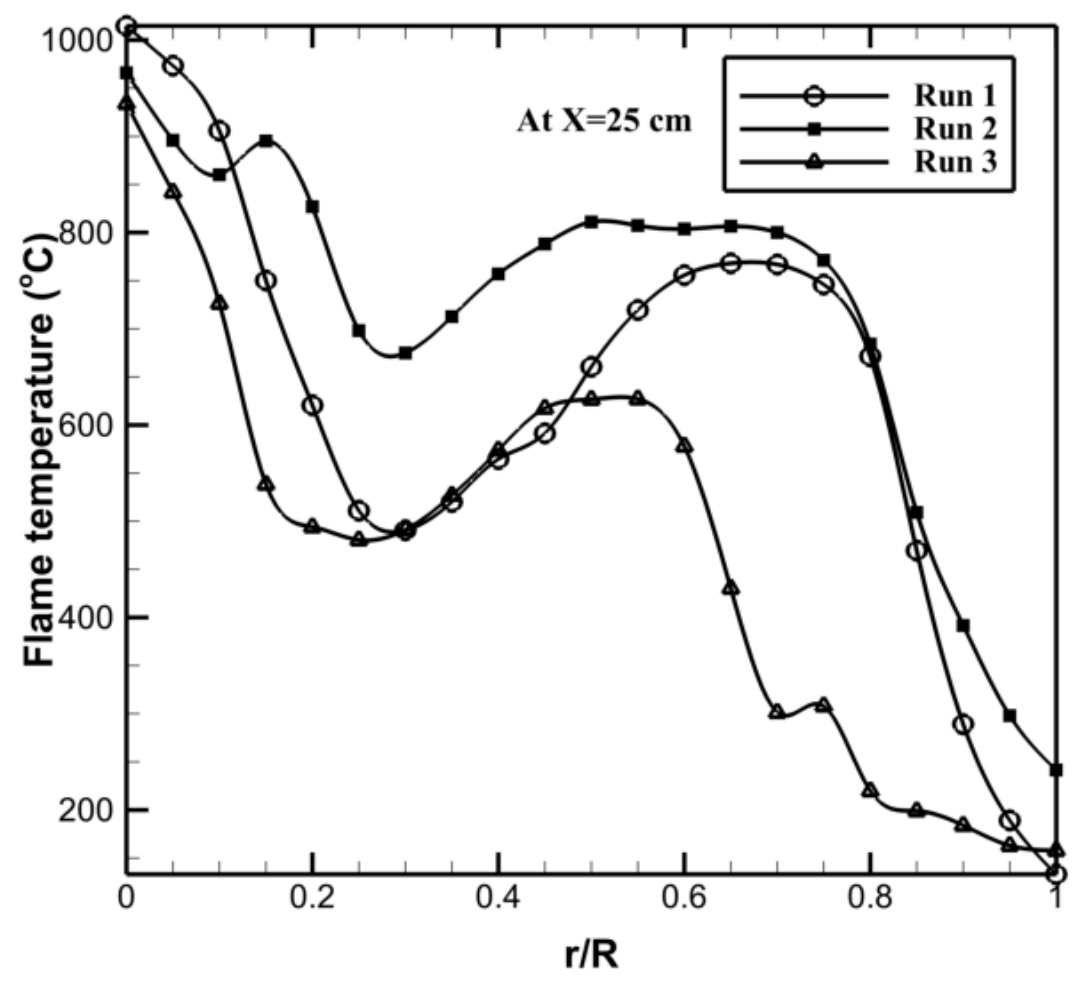

Figure 5 Radial profiles of flame temperature at an axial location $\mathrm{X} / \mathrm{D}=0.625$ of run 1, 2 and 3.

Figure 6 shows the distribution of the heat transfer rate to the cooling water jacket for the same input heat and different air: fuel ratios, for diesel oil and at different percentages of EC and water in the diesel oil. It was observed that the ECOWS fuel with contents (Run $2: 10 \%$ coal, $10 \%$ water) gives heat transfer to the cooling water jacket higher than that of the pure diesel oil(run 1), hence higher combustion efficiency. This was due to the presence of coal particles in the slurry which have a higher emissivity than diesel oil, which enhance the rate of heat transfer by radiation to the water jacket. As the percentages of the EC and water were increased further to $15 \mathrm{wt} \%$ in the diesel oil for each (Run 3), the heat transfer to the water jacket decreased to be lower than that of run 1 This was due to the lower calorific value of the EC compared with the diesel oil and 
nearby zero calorific value of water. This figure also hence combustion improvement (i.e. greater heat transfer to the cooling water jacket) for ECOWS fuel with loading ratios of coal and water in run 2 over pure diesel oil in the downstream section of the combustor.

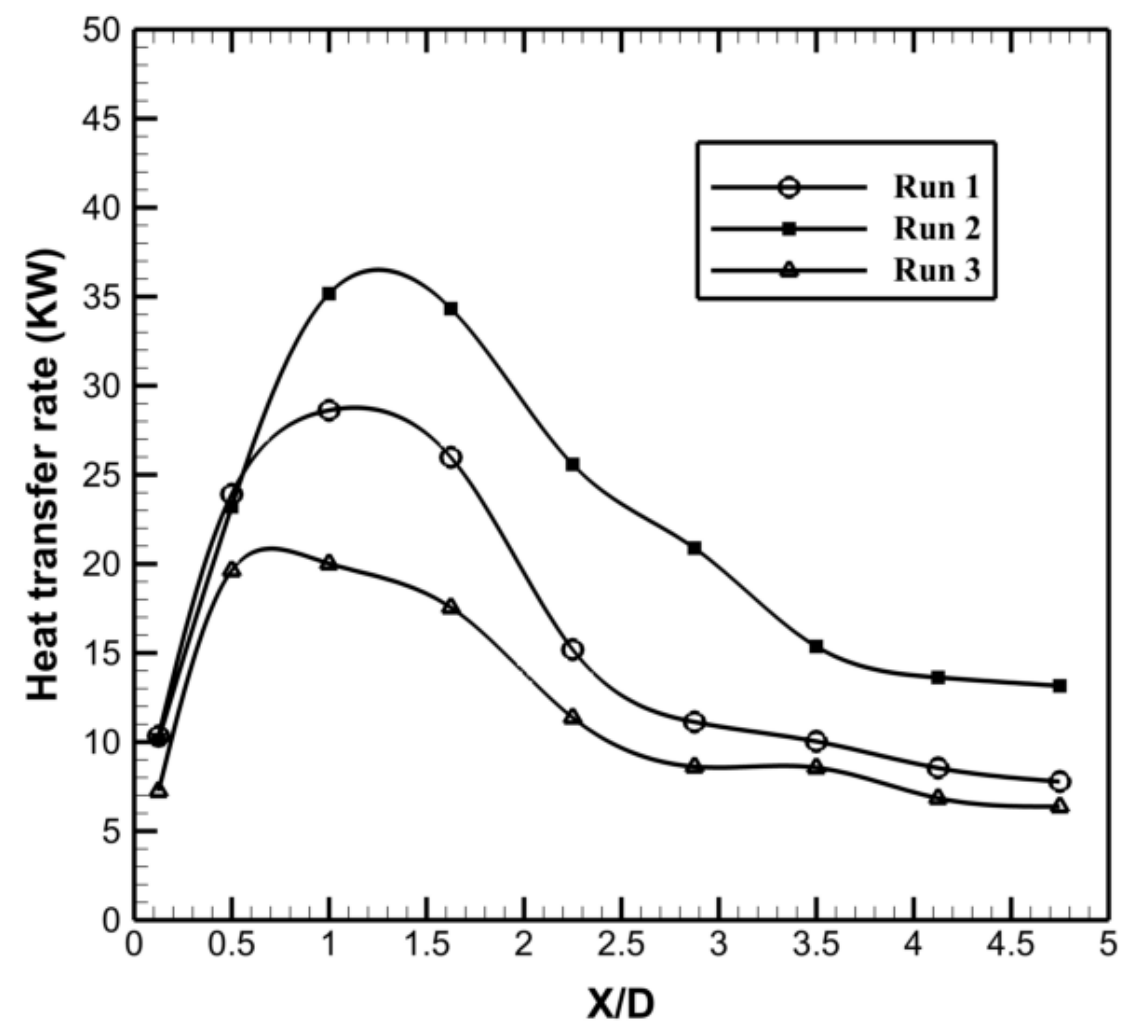

Fig. 6 Heat transfer rate distribution to the cooling water jacket.

Figure 7 shows the effect of varying the slurry components concentration in diesel oil on the axial distribution of heat flux intensity along the wall under constant heat input. As a common feature all curves exhibit the same trend. It was noticed that, the peak value of the heat flux occurs near the burner end occasionally at $\mathrm{X} / \mathrm{D}=1.2$, this due to intense combustion zone at this region. At downstream sections, where the combustor is filled with the combustion gases the heat flux decreases gradually and in this region the heat transfer is dominated by convection. Also it's observed that, increasing the coal and 
water percentages to $15 \mathrm{Wt} \%$; for each, in diesel oil, the heat flux to the walls along the combustor slightly decreased than that of pure diesel oil as a result of decreasing the calorific value of the slurry.

This figure also shows that ECOWS fuel of loading ratios of $10 \%$ coal, $10 \%$ water (Run 2) gives an accumulative heat distribution higher than that of pure diesel oil (Run 1) but by increasing the ratios of coal and water in the slurry to $15 \%$ for each (Run 3), the accumulative heat decreased to provide the least distribution curve of whole runs.

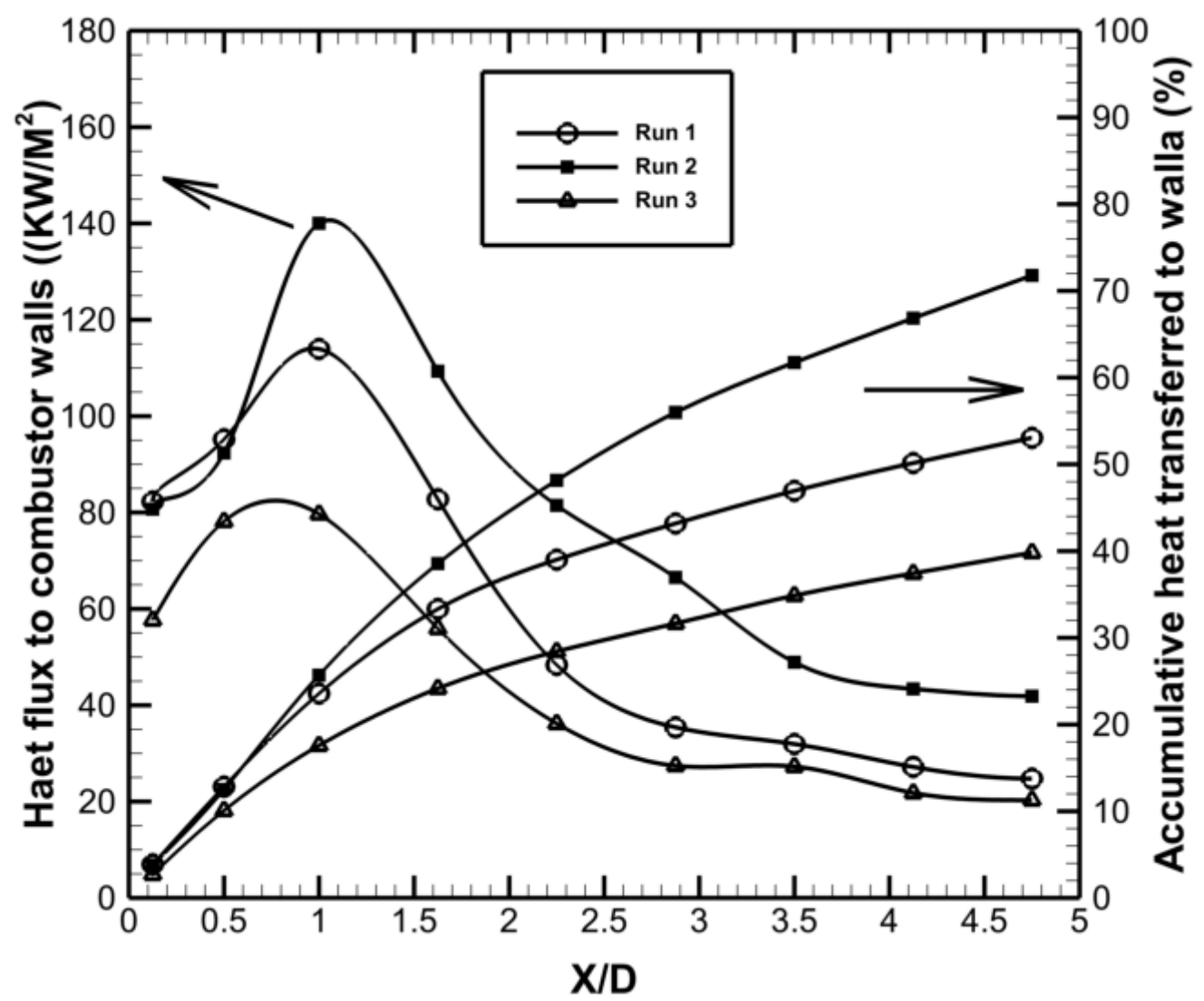

Fig.7 Heat flux and accumulative heat distributions to the water jacket along the combustor axis.

Figure 7 shows the variation of $\mathrm{CO}_{2}$ and $\mathrm{O}_{2}$ concentrations along the combustor axis. It was observed in all experiments that the concentration of $\mathrm{CO}_{2}$ starts to increase to reach its maximum value at the second section which goes towards highest chemical reaction 
zone and promotes better mixing and interaction between fuel jet and air streams. At the upstream sections, the $\mathrm{CO}_{2}$ has higher values in case of ECOWS (10\% coal, $10 \%$ water) than that of pure diesel oil and ECOWS (15\% coal, $15 \%$ water). It is noticed that the concentration of carbon dioxides has maximum value $14.7 \%$ at axial location $\mathrm{X} / \mathrm{D}=0.875$ corresponding to maximum axial temperature and that enhances the description mentioned above, where the fuel stream consumes most of oxygen at this region (central recirculation zone) to burn completely with oxygen corresponding concentration of $0.5 \%$, then the concentration of $\mathrm{CO}_{2}$ starts to decrease at the downstream sections as the outer chemical reaction zones are less intensity. Correspondingly, the concentration of $\mathrm{O}_{2}$ starts to decrease gradually until it is consumed approximately completely at the upstream section corresponding to maximum concentration of $\mathrm{CO}_{2}$ where complete combustion is achieved, then starts to increase at the downstream section reaching maximum concentration at the end of combustor away from the intensive circulation zones and reversed mass. 


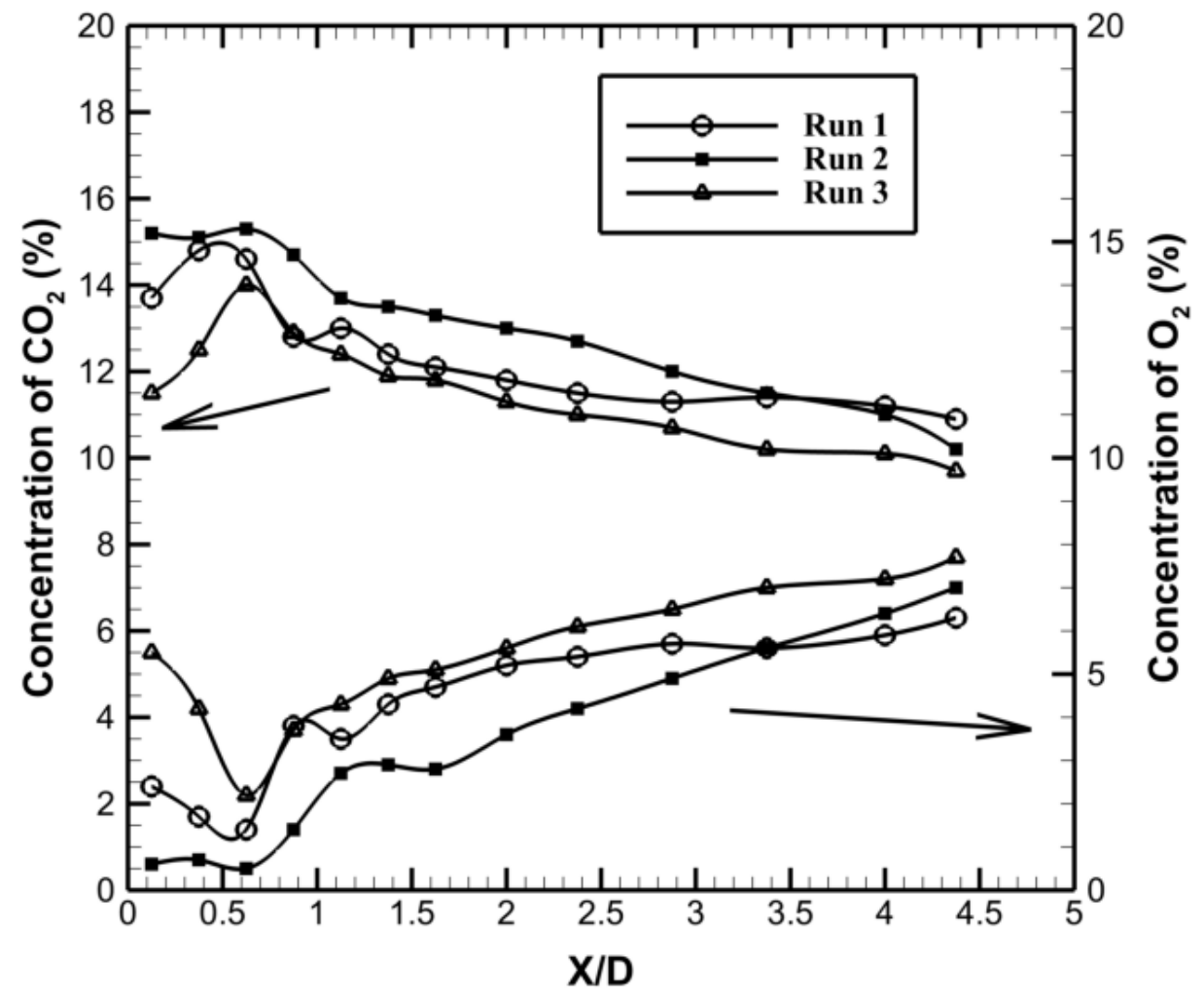

Fig. 8 Axial Concentration of carbon dioxide and oxygen.

Figure 9 shows the variation of $\mathrm{NO}_{\mathrm{x}}$ (nitrogen oxides) concentrations along the combustor axis. Nitrogen oxides can be formed from both fuel nitrogen (the volatile nitrogen released from the coal) and atmospheric nitrogen. The figure shows that $\mathrm{NO}_{\mathrm{x}}$ formation is higher in run 2 than the reference case (run 1) where the maximum temperatures exist at $0.625 \leq \mathrm{X} / \mathrm{D} \leq 0.875$. It was observed that NOx reported its lower levels in case of ECOWS (Run 3:15\% coal,15\% water) due to the declination of temperature generally along the combustor length. 


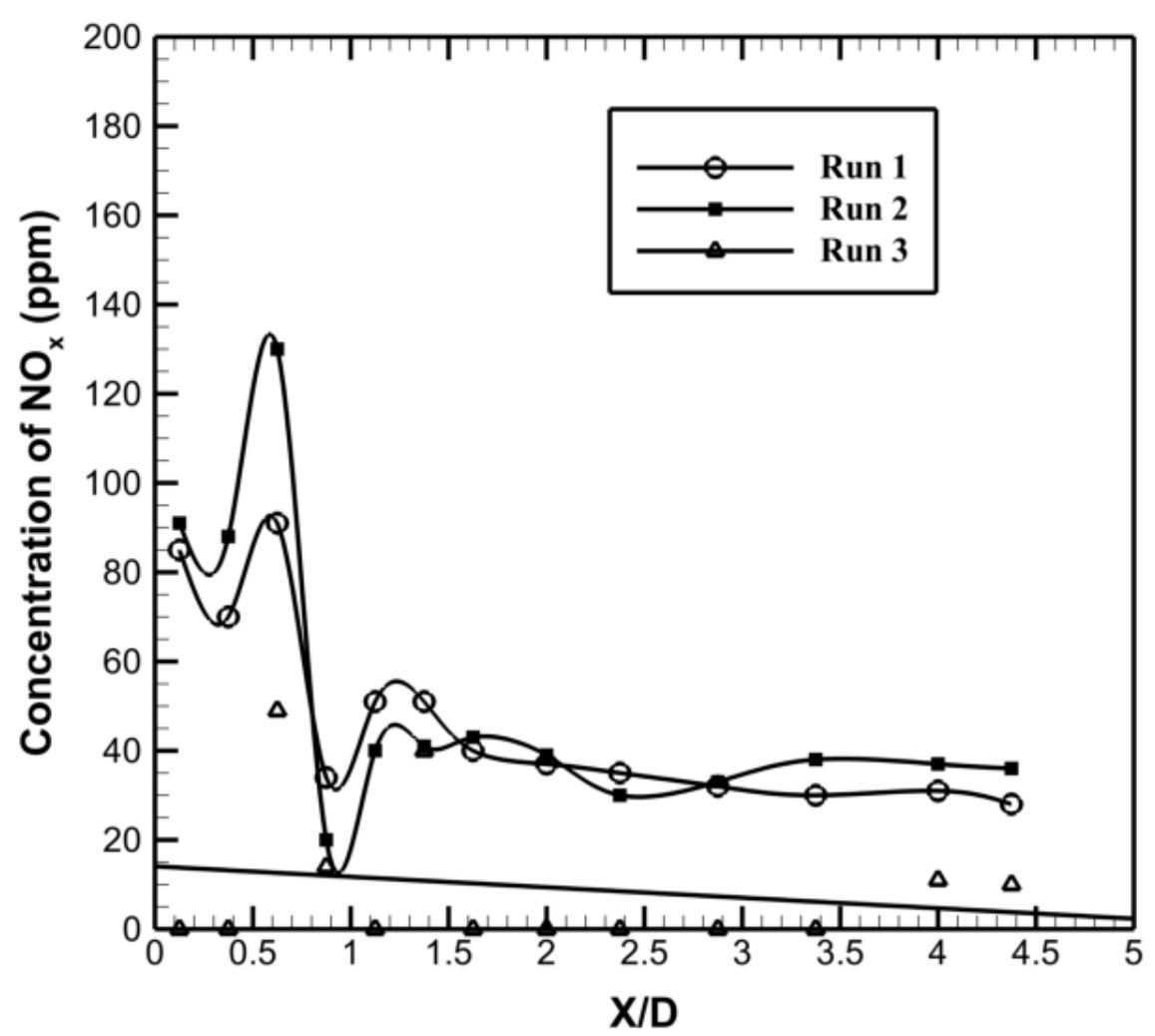

Fig.9 Axial concentration of Nitrogen oxides.

\section{5-Conclusions}

An important and significant alternative fuel has been proposed. The combustion characteristics in terms of the rate of heat transfer, the accumulative heat, heat flux and concentrations of combustion products of ECOWS flames have been improved when coal and water were added by $10 \% \mathrm{Wt}$. for each in the diesel oil, accompanied with higher thermal efficiency and slightly decrease in the maximum flame temperature compared to that of pure diesel oil flame. While increasing the loading ratios of coal and water to $15 \% \mathrm{wt}$. in the diesel oil contributes to further decrease in combustion characteristics, accompanied with lower thermal efficiency and reported the lowest values of $\mathrm{NO}_{\mathrm{x}}$ emissions. From the experimental data analysis, it's concluded that the 
ECOWS fuel is a good alternative source of energy that can be used widely in industrial furnaces.

\section{References}

[1] Lee, S., Speight, J.G. and Loyalka, S.K. "Handbook of Alternative Fuel Technologies", Physical chemistry chemical physics", PCCP, Vol. 9, No. 12., p. $671,2015$.

[2] Zhu, H., Yan,X., Xia, J. and Li, Y., "Preparation and rheological properties of oilwater-coal triplex synfuel using petroleum sulfonate as the dispersants", Fuel Process. Technol., Vol. 88, No. 3, pp. 221-225, 2007.

[3] Qi, H.L., Gai, K., Ma, D.P.and Zheng, B., "Study on the Preparation of Oil-CoalWater Slurry", Applied Mechanics and Materials, vol. 716-717, pp. 11-15, 2014.

[4] Shukla, S.C., Kukade, S., Mandal, S.K. and Kundu, G., "Coal-oil-water multiphase fuel: Rheological behavior and prediction of optimum particle size", Fuel, Vol. 87, No. 15-16, pp. 3428-3432, 2008.

[5] Majumder, S.K., Chandna, K., De, D.S. and G. Kundu, G., "Studies on flow characteristics of coal - oil - water slurry system”, Spring, Vol. 79, pp. 217-224, 2006.

[6] Ibrahim, S.S., EL Anadoly, B.E., Farahat, M.M., Selim, A.Q. and El-Menshawy, A.H., "Separation of pyritic sulfur from Egyptian coal using falcon concentrator", Particulate Science and Technology, Vol. 32, pp.588-594, 2014.

[7] Douglas, C.R., Paul, O.H.and Douglas, S.L., "Laboratory-scale combustion of coal-water mixtures", Combustion and Flame, Vol.63, pp.59-72, 1986. 